\title{
Kedudukan Memorandum Of Understanding dan Surat Keputusan Bersama Ditinjau dari Teori Perundang-undangan
}

\author{
Zayanti Mandasari \\ Pascasarjana Fakultas Hukum Universitas Islam Indonesia \\ Jl. Cik Di Tiro No. 1 Yogyakarta \\ Smanda79@yahoo.com
}

\begin{abstract}
This research emphasizes on the issue on the status of MoU (Master of Understanding) and SKB (Joint Decree) in the perspective of regulatory theories, binding power and implication of MoU and SKB towards the institutions and/or commission issuing it. This is a normative legal research with the secondary data in the form of primary, secondary and tertiary law materials using a regulatory approach. The results of this result then show that: first, SKB (Joint Decree) about the ethic code and Guidelines of Judge Attitude in the perspective of regulatory theory can be categorized as a policy regulation. MoU about the Optimality of Corruption Eradication in the perspective of regulatory theories is not able to be categorized as a part of regulations. Second, the SKB (Joint Decree) has a strong binding power towards MA (Supreme Court) and KY (Judicial Commission). MoU has emerged a binding power to KPK (Committee of Corruption Eradication), POLRI (Indonesian Police) and Kejari (District Attorney) since it is in Agreement is Agreement category that binds all parties. Third, SKB about Ethic Code and Judge Attitude Guidelines emerges an implication that MA and KY must obey SKB that has been made altogether. MoU about the Optimization of Corruption Eradication emerges an implication resembling to Agreement is Agreement. Hence, KPK, Polri and Kejari must obey all agreements.
\end{abstract}

Key words : Legislation, MoU, SKB (joint decree)

\begin{abstract}
Abstrak
Penelitian ini mengangkat permasalahan kedudukan MoU dan SKB ditinjau dari teori perundangundangan, daya ikat dan implikasi MoU dan SKB terhadap lembaga dan/atau komisi yang membuatnya. Penelitian ini merupakan penelitian hukum normatif dengan sumber data sekunder yang berupa bahan hukum primer, sekunder dan tersier. Pendekatan yang digunakan adalah pendekatan perundangundangan. Hasil penelitian ini menyimpulkan bahwa: pertama, Surat Keputusan Bersama tentang Kode Etik dan Pedoman Perilaku Hakim ditinjau dari teori perundang-undangan dapat dikategorikan sebagai peraturan kebijakan. MoU tentang Optimalisasi Pemberantasan Tindak Pidana Korupsi ditinjau dari teori perundang-undangan tidak dapat dikategorikan sebagai bagian dari peraturan perundangundangan. Kedua, Surat Keputusan Bersama memiliki daya ikat yang kuat terhadap MA dan KY. MoU minimbulkan daya ikat terhadap KPK, Polri dan Kejari karena MoU kategori Agrement is Agrement yang mengikat para pihak. Ketiga, Surat Keputusan Bersama tentang Kode Etik dan Pedoman Perilaku Hakim menimbulkan implikasi bahwa MA dan KY harus mentaati SKB yang telah dibuat bersama. MoU tentang Optimalisasi Pemberantasan Tindak Pidana Korupsi menimbulkan implikasi layaknya perjanjian Agrement is Agrement sehingga KPK, Polri dan Kejari harus mentaati seluruh kesepakatan.
\end{abstract}

Kata Kunci : Peraturan Perundang-undangan, MoU, SKB 


\section{Pendahuluan}

Peraturan perundang-undangan merupakan salah satu hal yang penting dalam kehidupan berbangsa dan bernegara, terlebih lagi telah ditegaskannya bahwa "Negara Indonesia adalah negara hukum" (Pasal 1 ayat (3) Undang Undang Dasar 1945). Kedudukan peraturan perundang-undangan dalam sistem hukum adalah termasuk dalam lingkungan hukum tertulis. ${ }^{1}$ Peraturan perundangundangan sebagai salah satu instrumen untuk menjalankan atau mewujudkan negara hukum. Di Indonesia pengaturan mengenai pembentukan peraturan perundang-undangan saat ini diatur dalam UU No. 12 Tahun 2011 tentang Pembentukan Peraturan Perundang-undangan, yang secara garis besar bersisi asas pembentukan, materi muatan, proses, bahkan mengatur tentang hierarki peraturan perundang-undangan tersebut. Pembagian tersebut ditujukan agar semua peraturan perundang-undangan dapat dilaksanakan dan berjalan dengan baik serta tidak terjadi tumpang tindih antara satu peraturan dengan paturan yang lainnya.

Di dalam praktek, sering ditemui adanya bermacam-macam bentuk produk hukum, semacam peraturan perundang-undangan yang dibuat oleh beberapa lembaga negara atau komisi negara atau antara lembaga negara dengan komisi negara, misalnya dalam bentuk Memorandum of Understanding (MoU) atau Surat Keputusan Bersama (SKB). Misalnya, MoU antara Kejaksaan Republik Indonesia (Kejari), Kepolisian Negara Republik Indonesia (Polri), Komisi Pemberantasan Korupsi Republik Indonesia (KPK); Surat Keputusan Bersama (SKB) yang dibentuk oleh Ketua Mahkamah Agung (MA) dan Ketua Komisi Yudisial (KY), serta Peraturan Bersama antara MA dengan KY.

Beberapa saat yang lalu terjadi 'kisruh' antara lembaga negara dengan komisi negara terkait dengan kewenangannya, seperti KPK dan Polri yang berseteru terkait penanganan kasus dugaan korupsi simulator SIM di Korlantas. ${ }^{2}$ Perseteruan ini terjadi karena pada 2012 telah dibuat sebuah kesepakatan bersama atau yang sering disebut dengan Memorandum of Understanding (MoU) ${ }^{3}$ antara Kejaksaan Republik

\footnotetext{
${ }^{1}$ Hukum tertulis yang berlaku umum (algemeen geldend) dan mengikat orang banyak (algemen bindend) serta mempunyai lingkup prilaku wilayah manusia (personengebeid), wilayah ruang (ruimtegebeid), dan wilayah waktu (tijdsgebeid) yang lebih luas, tidak mempunyai kedudukan yang lebih tinggi daripada hukum tidak tertulis lihat dalam Soerjono Soekanto dan Purnadi Purbacaraka, Perihal Kaidah Hukum, PT Citra Aditya, Bandung, 1989, hlm. 6.

${ }^{2}$ SBY: Kasus Simulator SIM Serahkan ke KPK, http://www.tribunnews.com/2012/10/08/sby-kasus-simulator-sim-serahkan-ke-kpk, Senin, 8 Oktober 2012 21:03 WIB.

${ }^{3}$ Dalam dunia internasional MoU dikenal juga sebagai perjanjian internasional tertulis yang artinya bahwa setiap perjanjian internasional yang dituangkan dalam instrumen-instrumen pembentuk perjanjian yang tertulis dan formal.
} 
Indonesia (Kejari), Kepolisian Negara Republik Indonesia (Polri), Komisi Pemberantasan Korupsi Republik Indonesia (KPK). Nomor: KEP-049/A/J.A/03/ 2012, Nomor: B/23/III/2012, dan Nomor: SP3-39/01/03/2012 tentang Optimalisasi Pemberantasan Tindak Pidana Korupsi. Polri bersikukuh ingin tetap menangani kasus dugaan korupsi simulator SIM di Korlantas Polri, yang pada saat itu juga telah ditangani KPK. Polri berdalih bisa menangani kasus itu karena adanya MoU antara KPK, Polri dan Kejagung. Tetapi di lain pihak KPK berdalih sebaliknya, dalam MoU tersebut justru terdapat beberapa pasal yang menguatkan KPK sebagai pihak yang seharusnya menangani kasus tersebut.

Kesepakatan tiga lembaga ini sebenarnya tidak lazim diatur dalam MoU karena MoU hanyalah mengikat secara 'moral' bagi para pihak yang membuatnya. Padahal maksud dibuatnya kesepakatan di antara mereka untuk mengoptimalkan kerja pemberantasan korupsi. Di samping itu, secara umum dipahami oleh masyarakat, MoU bukan merupakan peraturan perundang-undangan, sehingga apabila di kemudian hari timbul persoalan di antara lembaga yang membuatnya atau timbul benturan dengan peraturan perundang-undangan, bagaimana penyelesaiannya, serta aturan manakah yang harus digunakan.

Selain kesepakatan yang dikukuhkan dalam MoU antara KPK, Polri dan Kejari, dalam praktek juga ditemui adanya suatu Surat Keputusan Bersama (SKB) yang dibentuk oleh Ketua Mahkamah Agung (MA) dan Ketua Komisi Yudisial (KY). ${ }^{4}$ SKB ini dibentuk dengan tujuan untuk memastikan agar hakim di dalam lingkungannya mematuhi Kode Etik dan Pedoman Perilaku Hakim yang telah ditentukan. Seiring berjalannya waktu, SKB yang telah disepakati oleh kedua belah pihak ternyata menimbulkan persoalan. Persoalan ini muncul ketika 4 (empat) orang pengacara mantan hakim mengajukan permohonan uji materil (Judicial Review/JR) terhadap SKB kepada MA. ${ }^{5}$ September 2012 MA dan KY kembali membentuk suatu

\footnotetext{
Maksudnya adalah perjanjian ini dituangkan dalam suatu instrumen tertulis yang pembentukannya memiliki prosedur atau aturan tertentu berdasarkan hukum internasional, sehingga instrumen tertulis itu menjadi instrumen otentik. Lihat dalam F.A. Whisnu Situni, Identifikasi dan Reformasi Sumber-Sumber Hukum Internasional, Cetakan I, Mandar Maju, Bandung, 1989, hlm 32-33.

${ }^{4}$ Keputusan Bersama Ketua Mahkamah Agung Republik Indonesia dan Ketua Komisi Yudisial Republik Indonesia Nomor : 047/KMA/SKB/IV/2009 Nomor : 02/SKB/P.KY/IV/2009 tentang Kode Etik dan Pedoman Perilaku Hakim.

${ }^{5}$ Ketentuan atau Pasal yang menjadi objek JR adalah Pasal 8 butir 1, 2, 3 dan 4 serta Pasal 10 butir 1, 2, 3 dan 4 SKB KetuaMA-Ketua KY. Putusan yang diberikan oleh majelis hakim agung terhadap permohonan uji materi No. 36 P/HUM/2011 adalah “membatalkan” delapan point yang ada dalam SKB Kode Etik dan Pedoman Perilaku Hakim (PPH) Tahun 2009.
} 
kesepakatan bersama yang disebut dengan Peraturan Bersama. Melalui Peraturan Bersama ini MA dan KY kembali menandatangani empat peraturan bersama. ${ }^{6}$

Melihat fenomena kemunculan MoU dan SKB yang dibuat oleh lembaga-lembaga negara ataupun komisi-komisi negara, dikhawatirkan akan muncul kembali konflik antarlembaga negara atau komisi negara, yang malah mengakibatkan terhambatnya kinerja masing-masing lembaga, dan bahkan dapat mengacaukan peraturan perundang-undangan yang telah ditentukan dalam UU No. 12 Tahun 2011.

\section{Rumusan Masalah}

Berdasarkan uraian dari latar belakang masalah di atas, dapat dirumuskan beberapa permasalahan sebagai berikut: pertama, bagaimana kedudukan MoU dan SKB ditinjau dari teori perundang-undangan? Kedua, bagaimana daya ikat MoU dan SKB terhadap pihak yang terkait (lembaga dan/atau komisi negara)? Ketiga, apa implikasi yang timbul dengan dibentuknya MoU dan SKB tersebut terhadap lembaga/komisi negara yang membuatnya?

\section{Tujuan Penelitian}

Berdasarkan rumusan masalah di atas, maka tujuan yang hendak dicapai dalam penelitian ini adalah: pertama, untuk mengetahui dan memahami kedudukan MoU dan SKB ditinjau dari teori perundang-undangan. Kedua, untuk menganalisis sejauhmana MoU dan SKB tersebut dapat mengikat pihak yang terkait di dalamnya. Ketiga, untuk mengetahui implikasi dari dibentuknya MoU dan SKB tersebut terhadap lembaga yang membuatnya.

\section{Metode Penelitian}

Penelitian ini adalah penelitian hukum (normatif), yaitu penelitian yang dilakukan dengan cara meneliti bahan pustaka (library research), dengan fokus kajian

\footnotetext{
${ }^{6}$ Empat peraturan bersama dimaksud adalah Peraturan Bersama tentang Majelis Kehormatan Hakim, Peraturan Bersama tentang Pelaksanaan Pemeriksaan Bersama, Peraturan Bersama tentang Juklak Kode Etik dan Pedoman Perilaku Hakim, dan Peraturan Bersama tentang Seleksi Pengangkatan Hakim. Dalam Keputusan Bersama Ketua Mahkamah Agung Republik Indonesia dan Ketua Komisi Yudisial Republik Indonesia Nomor: Peraturan Bersama Mahkamah Agung Republik Indonesia dan Komisi Yudisial Republik Indonesia No. 02/PB/MA/IX/2012, No. 02/ PB/P.KY/09/2012 tentang Panduan Penegakan dan Kode Etik dan Pedoman Perilaku Hakim.
} 
sebagai berikut: 1. MoU antara Kejaksaan Republik Indonesia, Kepolisian Negara Republik Indonesia, Komisi Pemberantasan Korupsi Republik Indonesia. Nomor: KEP-049/A/J.A/03/2012, Nomor: B/23/III/2012, dan Nomor: Spj-39/01/03/2012 tentang Optimalisasi Pemberantasan Tindak Pidana Korupsi. 2. Surat Keputusan Bersama Ketua Mahkamah Agung Republik Indonesia dan Ketua Komisi Yudisial Republik Indonesia Nomor: 047/KMA/SKB/IV/2009 Nomor: 02/SKB/P.KY/IV/ 2009 tentang Kode Etik dan Pedoman Perilaku Hakim.

Dalam penelitian ini pengumpulan data dilakukan dengan cara studi dokumen, yaitu mengkaji, menelaah dan mempelajari bahan-bahan hukum yang mempunyai keterkaitan dengan penelitian ini. Di samping itu, juga dilengkapi dengan wawancara dengan para ahli yang kompeten, untuk mempertajam analisis. Penelitian ini menggunakan pendekatan perundang-undangan (statute approach) karena bahan utama yang dianalisis adalah MoU antara Kejaksaan Republik Indonesia, Kepolisian Negara Republik Indonesia, Komisi Pemberantasan Korupsi Republik Indonesia, serta Surat Keputusan Bersama antara Mahkamah Agung Republik Indonesia dengan Komisi Yudisial Republik Indonesia. Metode analisis bahan hukum yang dipergunakan dalam penelitian ini adalah deskriptif kualitatif, yaitu bahan hukum yang diperoleh dari penelitian disajikan dan diolah secara kualitatif.

\section{Hasil Penelitian dan Pembahasan}

\section{Kedudukan MoU Ditinjau dari Teori Perundang-undangan}

MoU yang dibentuk oleh KPK, Polri dan Kejari tentang Optimalisasi Pemberantasan Tindak Pidana Korupsi ${ }^{7}$ dibuat dengan tujuan mengoptimalkan pemberantasan tindak pidana korupsi di Indonesia dengan mensinergikan tiga lembaga yang memang secara legal memiliki kewenangan dalam hal penanganan kasus tindak pidana korupsi.

Berdasarkan nomenklatur yang tertera dalam kesepakatan ini adalah Kesepakatan Bersama antara Kejaksaan Republik Indonesia, Kepolisian Negara Republik Indonesia dan Komisi Pemberantasan Korupsi (selanjutnya disebut MoU). Istilah MoU ini, tidak ditemukan dalam tata urutan peraturan perundang-undangan

\footnotetext{
${ }^{7}$ Kesepakatan Berasama antara Kejaksaan Republik Indonesia, Kepolisian Republik Indonesia dan Komisi Pemberantasan Korupsi Republik Indonesia. Nomor: KEP-094/A/J.A/03/2012, Nomor: B/23/III/2012, Nomor: Spj-39/01/03/2012 tentang Optimalisasi Pemberantasan Tindak Pidana Korupsi.
} 
Indonesia atau sering disebut dengan hierarki peraturan perundang-undangan, yang terdapat dalam Pasal 7 ayat (1) UU No. 12 Tahun 2011 tentang Pembentukan Peraturan Perundang-undangan, jenis peraturan perundang-undangan hanya terdiri atas: a. Undang-Undang Dasar Negara Republik Indonesia Tahun 1945; b. Ketetapan Majelis Permusyawaratan Rakyat; ${ }^{8}$ c. Undang-Undang/Peraturan Pemerintah Pengganti Undang-Undang; d. Peraturan Pemerintah; e. Peraturan Presiden; f. Peraturan Daerah Provinsi; ${ }^{9}$ dan g. Peraturan Daerah Kabupaten/Kota. Serta Pasal 7 ayat (2) yang berbicara tentang kekuatan hukum peraturan perundang-undangan sesuai dengan hierarki yang dimaksud dalam ayat (1) diatas. ${ }^{10}$ Dalam Pasal 8 ayat (1) juga terdapat jenis peraturan perundang-undangan lainnya yang berada di luar hierarki, yang mencakup: Peraturan yang ditetapkan oleh Majelis Permusyawaratan Rakyat, Dewan Perwakilan Rakyat, Dewan Perwakilan Daerah, Mahkamah Agung, Mahkamah Konstitusi, Badan Pemeriksa Keuangan, Komisi Yudisial, Bank Indonesia, Menteri, Badan, Lembaga, atau Komisi yang setingkat yang dibentuk dengan Undang-Undang atau Pemerintah atas perintah Undang-Undang, Dewan Perwakilan Rakyat Daerah Provinsi, Gubernur, Dewan Perwakilan Rakyat Daerah Kabupaten/ Kota, Bupati/Walikota, Kepala Desa atau yang setingkat. Dan dalam ayat (2) mengatakan bahwa, Peraturan Perundang-undangan sebagaimana dimaksud pada ayat (1) diakui keberadaannya dan mempunyai kekuatan hukum mengikat sepanjang diperintahkan oleh Peraturan Perundang-undangan yang lebih tinggi atau dibentuk berdasarkan kewenangan. ${ }^{11}$

Apabila dicermati, dalam Pasal 8 ayat (1) di atas dengan jelas menegaskan batasan atau ruang lingkup peraturan perundang-undangan yang diakui keberadaannya dan mempunyai kekuatan hukum di Indonesia. Berdasarkan hierarki peraturan perundang-undangan di atas, sama sekali tidak ditemukan pengaturan

${ }^{8}$ Yang dimaksud dengan "Ketetapan Majelis Permusyawaratan Rakyat" adalah Ketetapan Majelis Permusyawaratan Rakyat Sementara dan Ketetapan Majelis Permusyawaratan Rakyat yang masih berlaku sebagaimana dimaksud dalam Pasal 2 dan Pasal 4 Ketetapan Majelis Permusyawaratan Rakyat Republik Indonesia Nomor: I/MPR/ 2003 tentang Peninjauan terhadap Materi dan Status Hukum Ketetapan Majelis Permusyawaratan Rakyat Sementara dan Ketetapan Majelis Permusyawaratan Rakyat Tahun 1960 sampai dengan Tahun 2002, tanggal 7 Agustus 2003.

${ }_{9}$ Termasuk dalam Peraturan Daerah Provinsi adalah Qanun yang berlaku di Provinsi Aceh dan Peraturan Daerah Khusus (Perdasus) serta Peraturan Daerah Provinsi (Perdasi) yang berlaku di Provinsi Papua dan Provinsi Papua Barat.

${ }^{10}$ Dalam ketentuan ini yang dimaksud dengan "hierarki” adalah penjenjangan setiap jenis Peraturan Perundangundangan yang didasarkan pada asas bahwa Peraturan Perundang-undangan yang lebih rendah tidak boleh bertentangan dengan Peraturan Perundang-undangan yang lebih tinggi.

${ }^{11}$ Yang dimaksud dengan "berdasarkan kewenangan" adalah penyelenggaraan urusan tertentu pemerintahan sesuai dengan ketentuan Peraturan Perundang-undangan. 
mengenai MoU. Maka dapat disimpulkan berdasarkan hierarki peraturan perundang-undangan, “MoU bukanlah suatu peraturan perundang-undangan”. Pertanyaannya, masuk ke dalam kategori apakah MoU ini? Sebenarnya istilah MoU ini dikenal dalam ranah hukum perdata (yang akrab disebut sebagai kesepakatan, perjanjian, nota kesepahaman, dll). ${ }^{12} \mathrm{MoU}$ biasanya berisi kesepakatan-kesepakatan para pihak yang ditujukan untuk kepentingan para pihak yang terlibat didalamnya. ${ }^{13}$ Dalam MoU tentang Optimalisasi Pemberantasan Tindak Pidana Korupsi terdapat hal yang menarik, yakni bagaimana ketiga pihak yang terlibat didalamnya menuangkan kesepakatan-kesepakatan secara "tertulis", "konkrit atau pokok”, dan "seluruh pasal (terdiri dari 31 pasal) yang secara otomatis berlaku bagi para pihak", serta "memuat hak dan kewajiban, ${ }^{14}$ mulai dari tugas, wewenang dan kewajiban bagi para pihak. Kriteria "tertulis", "konkrit" atau "pokok", "ketentuan pasal berlaku bagi para pihak" tersebut merupakan kriteria dari MoU Agrement is Agrement. MoU Agrement is Agrement adalah sekali suatu perjanjian dibuat, apapun bentuknya baik lisan ataupun tertulis, pendek atau panjang, lengkap atau detail ataupun hanya diatur pokok-pokoknya saja, sehingga seluruh ketentuan pasal-pasal tentang hukum perjanjian telah bisa diterapkan keadaannya. ${ }^{15}$

Menurut pendapat ini, untuk mencari alasan yuridis yang tepat bagi penggunaan MoU terdapat dalam Pasal 1338 ayat (1) KUHPer yang artinya apapun yang dibuat sesuai kesepakatan kedua belah pihak, merupakan hukum yang berlaku baginya sehingga mengikat kedua belah pihak tersebut. Selain itu, menurut asas kebebasan berkontrak dan asas konsensual maka hal apa saja asalkan halal menurut hukum dan telah secara bebas disepakati maka berlaku suatu perjanjian atau jika diterapkan secara tertulis maka hal tersebut bisa dikatakan sebagai kontrak. ${ }^{16}$

Berdasarkan pengertian dan dasar hukum di atas, penulis menyimpulkan bahwa MoU Agrement is Agrement memiliki lima kriteria, yakni: pertama, bentuknya baik lisan ataupun tertulis, pendek atau panjang; kedua, lengkap atau detail ataupun ataupun hanya diatur pokok-pokoknya saja; ketiga, seluruh ketentuan pasal-pasal tentang hukum perjanjian langsung dapat diterapkan keadaannya; keempat, memuat

\footnotetext{
${ }^{12}$ F .A. Whisnu Situni, Identifikasi ..., Op. Cit., hlm. 32.

${ }^{13}$ Erman Rajagukguk, Kontrak Dagang Internasional dalam Praktek di Indonesia, FH UI dan Elips Project, Jakarta, 1994, hlm.1. Lihat juga dalam www.pps.unud.ac.id, "Tanggung Jawab Hukum Para Pihak".

${ }^{14}$ Salim HS, et, Al.,. Perancangan Kontrak dan MoU, cetakan ke 3, Sinar Grafika , Jakarta, 2008, hlm. 47.

${ }^{15}$ Munir Fuadi , Hukum Bisnis dalam Teori dan Praktek, Citra Aditya Bakti, Bandung, 2000, hlm. 92-94.

${ }^{16}$ Ibid.
} 
hak dan kewajiban bagi para pihak; kelima, terdapat jangka waktu berlakunya kesepakatan tersebut.

MoU tentang Optimalisasi Pemberantasan Tindak Pidana Korupsi, mengandung lima kriteria di atas. Hal ini seperti yang terdapat dalam MoU Nomor: KEP-049/A/J.A/03/2012, Nomor: B/23/III/2012, Nomor: Spj/39/01/03/2012 tentang Optimalisasi Pemberantasan Tindak Pidana Korupsi, dibuat secara tertulis dalam naskah resmi yang ditandatangani oleh Basrief Arief, Timur Pradopo, dan Abraham Samad sebagai pihak ${ }^{17}$ yang membuat kesepakatan. Maka MoU tentang Optimalisasi Pemberantasan Tindak Pidana Korupsi memenuhi kriteria yang pertama, yakni dibuat secara "tertulis".

MoU tentang Optimalisasi Pemberantasan Tindak Pidana Korupsi mengatur mengenai hal-hal yang pokok saja. Yang dimaksud mengatur hal yang pokok saja, adalah bahwa MoU hanya memuat tujuh kesepakatan pokok, yang tercantum dalam Pasal 4 mengenai ruang lingkup kesepakatan bersama, yang terdiri dari: a. Pencegahan tindak pidana korupsi; b. Penanganan perkara tindak pidana korupsi; c. Pengembalian kerugian keuangan negara perkara tindak pidana korupsi; d. Perlindungan hukum bagi pelapor dan saksi pelaku yang bekerjasama (whistleblower atau justice collaborators) dalam pengungkapan tindak pidana korupsi; e. Bantuan personil dalam penanganan perkara tindak pidana korupsi; f. Pendidikan/pelatihan bersama dalam penanganan perkara tindak pidana korupsi; dan g. Jumpa pers dalam rangka penanganan perkara tindak pidana korupsi. Dengan adanya pengaturan Pasal 4, maka MoU tentang Optimalisasi Pemberantasan Tindak Pidana Korupsi masuk ke dalam kriteria yang kedua yakni "memuat hal yang pokok-pokok" dalam hal ini yang pokok adalah materi MoU hanya mengatur atau fokus pada tujuh kesepakatan.

Pasal 29 menegaskan bahwa, “Apabila terdapat suatu ketentuan dalam Kesepakatan Bersama ini yang dilarang oleh ketentuan peraturan perundangundangan setelah ditandatanganinya Kesepakatan Bersama yang menyebabkan ketentuan tersebut menjadi tidak berlaku, maka hal tersebut tidak membatalkan ketentuan-ketentuan lainnya dalam Kesepakatan Bersama ini dan ketentuanketentuan lainnya dalam Kesepakatan Bersama ini tetap berlaku serta mengikat."

${ }^{17}$ Bahkan di dalam naskah MoU Nomor: KEP-049/A/J.A/03/2012, Nomor: B/23/III/2012, Nomor: Spj/ 39/01/03/2012 tentang Optimalisasi Pemberantasan Tindak Pidana Korupsi,yang ditandatangani Basrief Arief, Timur Pradopo, dan Abraham Samad, disebut dalam kolom tanda tangan sebagai "pihak", maka hal ini semakin mempertegas bahwa MoU ini merupakan bagian dari suatu kesepakatan atau perjanjian, karena istilah pihak tersebut lazim digunakan dalam ranah hukum perdata khususnya dalam perjanjian/kesepakatan. 
Ketentuan tersebut, menyatakan bahwa kesepakatan yang telah dibuat oleh para pihak berlaku bagi para pihak. Di samping itu, harus dicermati kata "mengikat", yang berarti MoU tentang Optimalisasi Pemberantasan Tindak Pidana Korupsi berlaku mengikat bagi para pihak dan seluruh kesepakatan yang tertuang di dalamnya dapat diberlakukan setelah kesepakatan ditandatangani. Hal ini berarti MoU tentang Optimalisasi Pemberantasan Tindak Pidana Korupsi mengandung kriteria yang ketiga, yakni: "seluruh ketentuan pasal-pasal tentang hukum perjanjian langsung dapat diterapkan keadaannya". Namun, dalam pasal ini juga terdapat ketentuan yang secara garis besar menyatakan "apabila terdapat suatu ketentuan dalam kesepakatan bersama ini yang dilarang oleh ketentuan peraturan perundangundangan, maka ketentuan yang bertentangan dengan ketentuan peraturan perundang-undangan itu dinyatakan tidak berlaku", hal ini berarti bahwa MoU tidak boleh bertentangan dengan ketentuan peraturan perundang-undangan yang lain.

Kata "mengikat" dalam ketentuan Pasal 29 tersebut, berarti kesepakatan yang dibuat oleh para pihak hanya berlaku bagi "pihak yang terlibat" di dalamnya. Hal ini semakin menjernihkan posisi bahwa MoU bukan merupakan peraturan perundangundangan, karena MoU tidak memenuhi unsur suatu aturan dapat dikatakan sebagai peraturan perundang-undangan. Menurut P.J.P Tak, yang dimaksud dengan peraturan perundang-undangan, yakni setiap keputusan tertulis yang dikeluarkan pejabat berwenang yang berisi aturan tingkah laku yang bersifat dan mengikat secara umum. ${ }^{18}$ Di samping itu, dalam Pasal 1 ayat (2) UU No. 12 Tahun 2012 juga dikatakan bahwa Peraturan Perundang-undangan adalah peraturan tertulis yang memuat norma hukum yang "mengikat secara umum" dan dibentuk atau ditetapkan oleh lembaga negara atau pejabat yang berwenang melalui prosedur yang ditetapkan dalam peraturan perundang-undangan. Apabila dijabarkan maka, suatu aturan yang dapat disebut dengan peraturan perundang-undangan harus memenuhi beberapa unsur, yakni: 1 . Peraturan tertulis; 2. Memuat norma hukum; 3. Berlaku dan mengikat secara umum; ${ }^{19}$ dan 4. Dibentuk oleh lembaga negara atau pejabat yang berwenang.

Pasal 8 ayat (1) yang menegaskan bahwa, “Dalam hal PARA PIHAK melakukan penyelidikan pada sasaran yang sama, untuk menghindari duplikasi penyelidikan

${ }^{18}$ Ni"matul Huda \& R. Nazriyah, Teori \& Pengujian Peraturan Perundang-undangan, Cetakan Pertama, Nusa Media, Bandung ,2011, hlm. 10.

${ }^{19}$ Berlaku dan mengikat secara umum maksudnya tidak mendefinisikan individu tertentu, sehingga berlaku bagi setiap subjek hukum yang memenuhi unsur-unsur yang terkandung dalam ketentuan mengenai pola tingkah laku tersebut. Lihat dalam Yuliandri, Asas-Asas Pembentukan Peraturan Perundang-Undangan Yang Baik, Cetakan Pertama, PT. Raja Grafindo Persada, Jakarta, 2009, hlm. 25. 
maka penentuan instansi yang "mempunyai kewajiban" untuk menindaklanjuti penyelidikan adalah instansi yang lebih dahulu mengeluarkan surat perintah penyelidikan atau atas kesepakatan PARA PIHAK; kemudian ayat (2) menyatakan "Penyidikan yang dilakukan pihak Kejaksaan dan pihak POLRI diberitahukan kepada pihak KPK, dan perkembangannya diberitahukan kepada pihak KPK paling lama 3 (tiga) bulan sekali"; Di dalam ayat (3) ditegaskan, "Pihak KPK menerima rekapitulasi penyampaian bulanan atas kegiatan penyidikan yang dilaksanakan oleh pihak Kejaksaan dan pihak Polri".

Pasal 20 ayat (1) menegaskan bahwa "Dalam rangka pelaksanaan Pasal 32 ayat (1) atau Pasal 33 Undang-Undang Nomor 31 Tahun 1999 tentang Pemberantasan Tindak Pidana Korupsi sebagaimana telah diubah dengan Undang-Undang Nomor 20 Tahun 2001, serta ditemukan adanya perorangan atau korporasi yang mendapatkan keuntungan secara tidak sah dari suatu tindak pidana korupsi berdasarkan putusan pengadilan, "PARA PIHAK wajib" menyerahkan dokumendokumen terkait, data dan informasi yang diperlukan kepada Jaksa Pengacara Negara untuk dilakukan tuntutan keperdataan. Kemudian di ayat (2) dinyatakan, “PARA PIHAK wajib memberikan bantuan seluas-luasnya, dalam rangka keberhasilan tuntutan keperdataan sebagaimana dimaksud ayat (1). Ketentuan di atas memuat "kewajiban bagi para pihak". Kesepakatan yang seperti ini masuk pada kriteria yang keempat, karena kewajiban para pihak itu telah dituangkan dalam MoU, yang dalam hal ini, dapat dilihat dari ketentuan yang menyatakan "para pihak mempunyai kewajiban untuk menindaklanjuti penyelidikan" dan "wajib menyerahkan dokumen", serta "wajib memberikan bantuan seluas-luasnya" ${ }^{20} \mathrm{Hal}$ ini senada dengan dasar yuridis penggunaan MoU sebagai Agrement is Agrement yang terdapat dalam Pasal 1338 ayat (1) KUHPer, yang menyatakan apapun yang dibuat sesuai kesepakatan kedua belah pihak, merupakan "hukum yang berlaku baginya" sehingga "mengikat kedua belah pihak" 21 tersebut. Selain itu menurut asas kebebasan berkontrak dan asas konsensual maka hal apa saja asalkan halal menurut hukum dan telah secara bebas disepakati maka berlaku suatu perjanjian

\footnotetext{
${ }^{20}$ Pasal 8 ayat (1) Kesepakatan Bersama antara Kejaksaan Republik Indonesia, Kepolisian Negara Republik Indonesia, dan Komisi Pemberantasan Korupsi. Nomor : KEP-049/A/J.A/03/2012, Nomor: B/23/III/2012, Nomor: Spj-39/01/03/2012)

${ }^{21}$ Ketentuan juga berisi unsur-unsur dalam hukum kontrak, yakni adanya kaidah hukum, subjek hukum, adanya prestasi yang dalam hal ini diharuskan berbuat sesuatu (menyerahkan dokumen, menindaklanjutu penyelidikan), terdapat kata sepakat, dan terdapat akibat hukum. Lihat dalam Salim H.S., Hukum Kontrak (Teori dan Teknik Penyusunan Kontrak), cetakan ketujuh, Sinar Grafika, Jakarta, 2010, hlm. 4-5.
} 
atau jika diterapkan secara tertulis maka hal tersebut bisa dikatakan sebagai kontrak. $^{22}$

Pasal 30 berisi klausul yang menyatakan bahwa "Kesepakatan Bersama ini berlaku selama 4 (empat) tahun dan mulai berlaku secara efektif terhitung sejak tanggal ditandatanganinya Kesepakatan Bersama", adanya jangka waktu yang ditentukan dalam MoU tentang Optimalisasi Pemberantasan Tindak Pidana Korupsi, maka masuk dalam kriteria yang kelima, yakni "memuat jangka waktu berlaku”. Adanya jangka waktu, juga merupakan ciri umum dari suatu kesepakatan atau perjanjian guna kepastian dalam pelaksanaan kesepakatan tersebut bagi para pihak.

Berdasarkan uraian tersebut di atas, dapat disimpulkan bahwa untuk mengetahui keedudukan dari MoU diperlukan suatu pengamatan yang jeli terhadap substansi yang terdapat dalam MoU tersebut. Substansi dalam MoU di atas sudah memenuhi unsur MoU sebagai Agrement is Agrement, karena dibuat secara tertulis, memuat hal yang pokok-pokok, berlaku dan mengikat bagi para pihak yang terlibat didalamnya yang dibuktikan dengan adanya hak dan kewajiban terhadap para pihak (seluruh ketentuan pasal-pasal tentang hukum perjanjian telah bisa diterapkan keadaannya, dalam hal ini seluruh kesepakatan), terdapat jangka waktu berlakunya kesepakatan, dan dapat diberlakukan mulai dari awal pembentukanya. Dengan demikian, MoU tersebut sudah berkedudukan sebagai kontrak dan dianggap sudah setingkat dengan perjanian berdasarkan Pasal 1338 KUHPer mengenai kebebasan berkontrak. ${ }^{23}$ Ditinjau dari keberlakuannya, MoU di atas hanya berlaku bagi para pihak (KPK, Polri dan Kejari) saja, dengan kata lain tidak berlaku umum, maka dengan adanya ketentuan ini, MoU tidak dapat dikatakan sebagai suatu peraturan perundang-undangan.

Selain tidak terdapat dalam hierarki peraturan perundang-undangan, $\mathrm{MoU}$ ini juga dapat dikatakan bukan merupakan peraturan perundang-undangan, karena setelah dianalisis ternyata MoU ini hanya berlaku dan mengikat antar para pihak saja, dan tidak berlaku umum. Berdasarkan ketentuan Pasal 1 ayat (2) UU No. 12 Tahun 2012 yang menegaskan, bahwa “Peraturan Perundang-undangan adalah peraturan tertulis yang memuat norma hukum yang "mengikat secara umum" dan dibentuk atau ditetapkan oleh lembaga negara atau pejabat yang berwenang melalui

${ }^{22}$ Munir Fuadi , Hukum Bisnis...., Op. Cit, hlm. 92-94.

${ }^{23}$ Dyah Aryani P, Sekilas Tentang MoU, (http//mediabersama.com/index.php/option=6 september 2009). dalam Pasal 31 ayat (1) MoU yang menegaskan "Kesepakatan Bersama ini dibuat dan ditandatangani pada waktu dan tempat sebagaimana tersebut di atas, dalam rangkap 3 (tiga) asli, masing-masing bermeterai cukup dan mempunyai kekuatan hukum yang sama setelah ditandatangani PARA PIHAK; bahwa dalam Pasal ini secara eksplisit menyebutkan 
prosedur yang ditetapkan dalam peraturan perundang-undangan. Apabila dijabarkan, suatu aturan dapat disebut sebagai peraturan perundang-undangan harus memenuhi beberapa unsur, yakni: 1. peraturan tertulis; 2 . memuat norma hukum; 3. berlaku dan mengikat secara umum; dan 4. dibentuk oleh lembaga negara atau pejabat yang berwenang. Berdasarkan unsur-unsur tersebut, MoU di atas bukan merupakan bagian dari peraturan perundang-undangan karena salah satu unsur peraturan perundangundangan yakni "berlaku dan mengikat secara umum" belum terpenuhi.

\section{SKB ditinjau dari Teori Perundang-undangan}

SKB yang ditandatangani oleh Ketua MA dan Ketua KY ${ }^{24}$ pada hakikatnya dibentuk dalam rangka mewujudkan suatu peradilan yang mandiri, netral (tidak berpihak), kompeten, transparan, berwibawa, yang diharapkan mampu menegakkan wibawa hukum dengan cara konkrit yakni melakukan kerja sama dalam mengawasi hakim melalui penyusunan formulasi baku kode etik bagi hakim. ${ }^{25}$

Seperti yang dikatakan di atas, bahwa salah satu tujuan dibentuknya SKB ini adalah untuk mewujudkan sikap netral (tidak berpihak), dalam SKB ini dituangkanlah dalam sub C butir 5. 1. 2., yang menegaskan, bahwa "hakim tidak boleh mengadili suatu perkara apabila memiliki konflik kepentingan, baik karena hubungan pribadi dan kekeluargaan, atau hubungan-hubungan lain yang beralasan (reasonable) patut diduga mengandung konflik kepentingan".

Apabila dicermati, sebenarnya butir 5.1.2 mengandung materi muatan peraturan perundang-undangan, khususnya Undang-Undang No. 48 Tahun 2009 tentang Kekuasaan Kehakiman, yakni dalam Pasal 17 ayat (3) menegaskan bahwa: “Seorang hakim wajib mengundurkan diri dari persidangan apabila terikat hubungan keluarga sedarah atau semenda sampai derajat ketiga, atau hubungan suami atau istri meskipun telah bercerai, dengan ketua, salah seorang hakim anggota, jaksa, advokat, atau panitera." Selain itu, materi tersebut juga berkaitan dengan Pasal 17 ayat (4) yakni: “ Ketua majelis, hakim anggota, jaksa, atau panitera wajib mengundurkan diri dari persidangan apabila terikat hubungan keluarga sedarah atau semenda sampai derajat ketiga, atau hubungan suami atau istri meskipun telah bercerai dengan pihak yang diadili atau advokat.

\footnotetext{
${ }^{24}$ Surat Keputusan Bersama Ketua Mahkamah Agung Republik Indonesia dan Ketua Komisi Yudisial Republik Indonesia Nomor : 047/KMA/SKB/IV/2009 NOMOR: 02/SKB/P.KY/IV/2009 tentang Kode Etik dan Pedoman Perilaku Hakim

${ }^{25}$ Tahun 2012, MA dan KY kembali membentuk suatu aturan mengenai kode etik dan prilaku hakim, yang di bentuk dalam "Peraturan Bersama Mahkamah Agung Republik Indonesia dan Komisi Yudisial Republik Indonesia Nomor. 01/PB/MA/IX/2012, Nomor. 01/PB/P.KY/09/2012 tentang Kode Etik dan Pedoman Preilaku Hakim”
} 
Dalam butir 5.1.2 ini juga disebutkan bahwa: hakim tidak boleh menangani perkara yang terdapat hubungan-hubungan lain yang beralasan (reasonable) patut diduga mengandung konflik kepentingan dengan hakim tersebut. Kalimat ini merupakan kristalisasi dari Pasal 17 ayat (5), yakni: “Seorang hakim atau panitera wajib mengundurkan diri dari persidangan apabila ia mempunyai kepentingan langsung atau tidak langsung dengan perkara yang sedang diperiksa, baik atas kehendaknya sendiri maupun atas permintaan pihak yang berperkara." 26 Bahkan dalam ayat (6) menegaskan bahwa "Dalam hal terjadi pelanggaran terhadap ketentuan sebagaimana dimaksud pada ayat (5), putusan dinyatakan tidak sah dan terhadap hakim atau panitera yang bersangkutan dikenakan sanksi administratif atau dipidana sesuai dengan ketentuan peraturan perundang-undangan". Hal ini berarti pengaturan yang terdapat dalam butir 5.1.2 SKB ini, mengandung materi muatan perundangundangan, maka dari itu pengaturan pada butir ini tidak tepat dikategorikan sebagai Keputusan (baca Keputusan Bersama) karena materi tersebut merupakan norma hukum sebagaimana yang telah diatur dalam UU No. 48 Tahun 2009 tentang Kekuasaan Kehakiman. Dengan demikian, tidak tepat apabila materi tersebut diatur hanya dengan Keputusan (SKB), seharusnya diatur dalam bentuk peraturan perundang-undangan.

“Hakim berkewajiban mengetahui dan mendalami serta melaksanakan tugas pokok sesuai dengan peraturan perundang-undangan yang berlaku, khususnya hukum acara, agar dapat menerapkan hukum secara benar dan dapat memenuhi rasa keadilan bagi setiap pencari keadilan", dan "Hakim harus menghormati hak-hak para pihak dalam proses peradilan dan berusaha mewujudkan pemeriksaan perkara secara sederhana, cepat dan biaya ringan." Kalimat di atas merupakan bagian dari butir yang terdapat di SKB, yakni butir 8.1. dan 8.2. Apabila di cermati kedua butir tersebut ternyata berisi "norma hukum", yang tepatnya norma hukum acara, termasuk di dalamnya asas-asas peradilan dan asas-asas umum peradilan yang baik (a lgemene beginse len van behoorljke rechtspraak) yang mengikat hakim dalam proses peradilan. Maka, sangat tidak cocok dengan judul SKB ini yang seharusnya memuat materi norma etik dan/atau norma perilaku. Seharusnya norma ini dimuat dalam peraturan yang yang lebih tinggi dan mempunyai daya ikat yang kuat seperti undang-undang yang berlaku dan mengikat secara umum. Sehingga dalam penerapannya lebih jelas dan mempunyai daya ikat yang kuat kepada umum.

${ }^{26}$ Dalam penjelasan Pasal 17 ayat (5) memberikan penjelasan yang lebih luas yakni dikatakan bahwa yang dimaksud dengan "kepentingan langsung atau tidak langsung" adalah termasuk apabila hakim atau panitera atau pihak lain pernah menangani perkara tersebut atau perkara tersebut pernah terkait dengan pekerjaan atau jabatan yang bersangkutan sebelumnya. 
Terkait dengan norma hukum acara yang dijelaskan di atas, ternyata juga terdapat dalam butir 8.3. yang mengatakan bahwa "Hakim harus membantu para pihak dan berusaha mengatasi segala hambatan dan rintangan untuk mewujudkan peradilan yang sederhana, cepat dan biaya ringan sesuai dengan peraturan perundang-undangan yang berlaku." Dan juga pada butir 8.4. yakni: “Ketua Pengadilan atau Hakim yang ditunjuk, harus mendistribusikan perkara kepada Majelis Hakim secara adil dan merata, serta menghindari pendistribusian perkara kepada Hakim yang memiliki konflik kepentingan." Hal ini semakin menunjukkan bahwa setiap butir yang terkandung dalam SKB adalah materi peraturan perundangundangan, karena memenuhi unsur-unsur yakni: 1) peraturan tertulis; 2) memuat norma hukum; 3) berlaku dan 4) mengikat secara umum;; dan 5) dibentuk oleh lembaga negara atau pejabat yang berwenang.

Berdasarkan analisis terhadap SKB tersebut dapat ditarik benang merah, bahwa apabila ditinjau dari teori perundang-undangan, SKB dapat dikategorikan sebagai peraturan kebijakan, tetapi tidak tepat jika dikatakan atau dinamakan dengan "keputusan" karena SKB ini tidak termasuk dalam keputusan, yang merupakan suatu penetapan tertulis yang dikeluarkan oleh Badan atau Pejabat Tata Usaha Negara yang berisi tindakan Hukum Administrasi Negara yang berdasarkan peraturan perundang-undangan yang berlaku, yang bersifat konkrit, individual ,dan final yang menimbulkan akibat hukum bagi seseorang atau Badan Hukum Perdata. Bahkan, SKB ini bersifat umum-abstrak bukan lagi individual-konkrit. ${ }^{28}$

Menurut Ridwan HR dan Zairin ${ }^{29}$, secara nomenklatur SKB ini tidak tepat di kategorikan dalam suatu “keputusan” karena mestinya aturan mengenai kode etik dimuat dalam bentuk peraturan, bukan dengan bentuk keputusan. Bahkan apabila dikaitkan dengan unsur-unsur suatu keputusan yakni: konkrit, individual, dan final, ${ }^{30}$

${ }^{27}$ Berlaku dan mengikat secara umum maksudnya tidak mendefinisikan individu tertentu, sehingga berlaku bagi setiap subjek hukum yang memenuhi unsur-unsur yang terkandung dalam ketentuan mengenai pola tingkah laku tersebut. Lihat dalam Yuliandri, Asas-Asas ..., Op. Cit., hlm. 25.

${ }^{28}$ Lihat dalam Pasal 1 angka 9 Undang-Undang No. 51 Tahun 2009 tentang Perubahan Kedua Atas UndangUndang Nomor. 5 Tahun 1986 tentang Peradilan Tata Usaha Negara. “Keputusan Tata Usaha Negara adalah suatu penetapan tertulis yang dikeluarkan oleh badan atau pejabat tata usaha negara yang berisi tindakan hukum tata usaha negara yang berdasarkan peraturan perundang-undangan yang berlaku, yang bersifat konkret, individual, dan final, yang menimbulkan akibat hukum bagi seseorang atau badan hukum perdata.

${ }^{29}$ Wawancara dengan Zairin SH.M.SI pada tanggal 22 Februari 2013 di Fakultas Hukum Universitas Islam Indonesia dan wawancara dengan Dr.Ridwan HR SH. M.Hum pada tanggal 23 Februari 2013 di Pascasarjana Fakultas Hukum Universitas Islam Indonesia.

${ }^{30}$ Lihat dalam Pasal 1 angka 9 Undang-Undang No. 51 Tahun 2009 tentang Perubahan Kedua Atas UndangUndang Nomor 5 Tahun 1986 tentang Peradilan Tata Usaha Negara. 
sama sekali tidak memenuhi unsur tersebut, karena materi muatan yang tertera dalam SKB ini justru bersifat dan bahkan merupakan materi muatan yang seharusnya ada pada tingkatan peraturan perundang-undangan.

Untuk membuktikan bahwa SKB ini sebenarnya tidak termasuk dalam kategori "keputusan", dapat dilakukan analisis berdasarkan unsur yang ada dalam keputusan, yakni: pertama: konkrit. Konkrit dalam SKB ini sama sekali tidak terpenuhi, karena dalam SKB ini pengaturan ditujukan kepada seluruh hakim yang ada di Indonesia, hal ini sama halnya seperti adanya pengaturan tentang Advokad, PNS dan lainnya. Seharusnya, agar dapat dikatakan sebagai suatu keputusan yang konkrtit, maka harus ditujukan kepada individu secara khusus.

Kedua, individual, artinya bahwa keputusan tersebut tidak ditujukan untuk umum, tetapi tertentu baik alamat maupun hal yang dituju. ${ }^{31}$ Apabila terdapat sebuah keputusan yang menyatakan kehendaknya dengan maksud terjadi perubahan dalam lapangan hukum publik yang bersifat umum, maka seharusnya dituangkan dalam bentuk Peraturan (Regelling). Sama halnya dengan SKB ini seharusnya dituangkan bukan dalam bentuk keputusan, seharusnya peraturan bersama. Ketiga, final, yang artinya keputusan tersebut telah bersifat definitif, sehingga oleh karena itu keputusan tersebut telah mempunyai akibat hukum.

Selain itu, dalam Pasal 7 ayat (1) UU No. 12 Tahun 2011, jenis peraturan perundang-undangan ditentukan terdiri atas: a. Undang-Undang Dasar Negara Republik Indonesia 1945; b. Ketetapan Majelis Permusyawaratan Rakyat; c. UndangUndang/Peraturan Pemerintah Pengganti Undang-Undang; d. Peraturan Pemerintah; e. Peraturan Presiden; f. Peraturan Daerah Provinsi; g. Peraturan Daerah Kabupaten/Kota. Kemudian dalam Pasal 7 ayat (2) mengatur tentang kekuatan hukum peraturan perundang-undangan sesuai dengan hierarki yang dimaksud dalam ayat (1). Dalam Pasal 8 ayat (1) juga terdapat jenis peraturan perundangundangan lainnya yang berada di luar hierarki, yang mencakup: Peraturan yang ditetapkan oleh Majelis Permusyawaratan Rakyat, Dewan Perwakilan Rakyat, Dewan Perwakilan Daerah, Mahkamah Agung, Mahkamah Konstitusi, Badan Pemeriksa Keuangan, Komisi Yudisial, Bank Indonesia, Menteri, Badan, Lembaga, atau Komisi yang setingkat yang dibentuk dengan undang-undang atau pemerintah atas perintah undang-undang, Dewan Perwakilan Rakyat Daerah Provinsi, Gubernur,

${ }^{31}$ SF. Marbun dan Moh. Mahfud MD, Pokok-Pokok. Hukum Administrasi Negara, Cetakan Kelima, Liberty, Yogyakarta, 2009, hlm. 91. 
Dewan Perwakilan Rakyat Daerah Kabupaten/Kota, Bupati/Walikota, Kepala Desa atau yang setingkat. Dan dalam ayat (2) mengatakan bahwa, peraturan perundangundangan sebagaimana dimaksud pada ayat (1) diakui keberadaannya dan mempunyai kekuatan hukum mengikat sepanjang diperintahkan oleh peraturan perundang-undangan yang lebih tinggi atau dibentuk berdasarkan kewenangan. ${ }^{32}$

Tidak ditemukan adanya pengaturan yang spesifik mengenai SKB ini, menurut Ridwan HR, ${ }^{33}$ menjadikan SKB ini tidak jelas atau "banci" karena dari segi nomenklaturnya adalah "keputusan" tetapi materi muatannya adalah "peraturan". Maka dapat diambil kesimpulan bahwa SKB ini apabila ditinjau dari hierarki peraturan perundang-undangan, tidak termasuk dalam peraturan perundang-undangan, tetapi masuk dalam peraturan kebijakan. Tetapi, apabila ditinjau dari materi muatan yang ada di dalamnya, maka SKB ini masuk dalam kategori "peraturan".

\section{Daya Ikat MoU}

MoU antara Kejari, Polri, dan KPK ini dibentuk guna mengoptimalkan pemberantasan tindak pidana korupsi di Indonesia khususnya di daerah. Dibentuknya MoU ini merupakan salah satu bentuk komitmen para penegak hukum dalam hal ini KPK, Polri, dan Kejari untuk mewujudkan Indonesia yang bebas korupsi. Dalam MoU ini juga terdapat berbagai pasal yang menyatakan bahwa para pihak dalam MoU ini masing-masing mempunyai kewajiban, seperti yang tercantum dalam Pasal 21 ayat $(1)^{34},(2)^{35}$, Pasal 21 ayat $(1)^{36}$ dan Pasal 16 ayat $(1)^{37}$. Adanya kewajiban-kewajiban yang dimuat dalam MoU ini, berarti mengatur para pihak yang

\footnotetext{
${ }^{32}$ Yang dimaksud dengan "berdasarkan kewenangan" adalah penyelenggaraan urusan tertentu pemerintahan sesuai dengan ketentuan peraturan perundang-undangan.

${ }^{33}$ Wawancara dengan Dr. Ridwan HR SH.M.Hum pada tanggal 23 Februari 2013, di Pascasarjana Fakultas Hukum Universitas Islam Indonesia.

${ }^{34}$ Dalam rangka pelaksanaan pasal 32 ayat (1) atau pasal 33 Undang-Undang Nomor 31 Tahun 1999 tentang Pemberantasan Tindak Pidana Korupsi sebagaimana telah diubah dengan Undang-Undang Nomor 20 Tahun 2001, serta ditemukan adanya perorangan atau korporasi yang mendapatkan keuntungan secara tidak sah dari suatu tindak pidana korupsi berdasarkan putusan pengadilan, PARA PIHAK wajib menyerahkan dokumen-dokumen terkait, data dan informasi yang diperlukan kepada Jaksa Pengacara Negara untuk dilakukan tuntutan keperdataan;

${ }^{35}$ PARA PIHAK wajib memberikan bantuan seluas-luasnya, dalam rangka keberhasilan tuntutan keperdataan sebagaimana dimaksud ayat (1).

${ }^{36}$ Dalam pelaksanaan Peraturan Bersama Nomor M.MH-11.HM.03.02 Tahun 2011; Nomor PER-045/A/JA/ 12/2011; Nomor 1 Tahun 2011; Nomor KEPB-02/01-55/12/2011; Nomor 4 Tahun 2011 tanggal 14 Desember 2011 tentang Perlindungan bagi Pelapor, Saksi Pelapor dan Saksi Pelaku yang Bekerjasama (whistleblower atau Justice Collaborators), PARA PIHAK menyepakati untuk melakukan koordinasi dalam hal Pelapor, Saksi Pelapor dan Saksi Pelaku yang Bekerjasama dilaporkan melakukan tindak pidana lain sebagai akibat laporan/ keterangannya.

${ }^{37}$ Guna mendukung keberhasilan pelaksanaan putusan pengadilan yang dilakukan oleh pihak Kejaksaan atau pihak KPK, PARA PIHAK memberikan bantuan personil dan pengamanan serta fasilitas sesuai dengan kewenangan masing-masing;
} 
terlibat didalamnya, sebagai konsekuensinya maka, MoU ini memiliki daya ikat yang kuat terhadap KPK, Polri dan Kejari. Hal ini juga tercermin dalam ketentuan Pasal 29 MoU ini, yang menegaskan bahwa "Apabila terdapat suatu ketentuan dalam Kesepakatan Bersama ini yang dilarang oleh ketentuan peraturan perundangundangan setelah ditandatanganinya Kesepakatan Bersama yang menyebabkan ketentuan tersebut menjadi tidak berlaku, maka hal tersebut tidak membatalkan ketentuan-ketentuan lainnya dalam Kesepakatan Bersama ini dan ketentuanketentuan lainnya dalam Kesepakatan Bersama ini tetap berlaku serta mengikat." Dengan adanya ketentuan ini, maka tidak dapat dipungkiri lagi bahwa pembentukan MoU ini memberikan daya ikat bagi para pihak dan oleh karena itu para pihak harus menjalankan semua kesepakatan yang dimuat dalam MoU ini, sepanjang tidak beetentangan dengan peraturan perundang-undangan lainnya.

Selain mengikat dikarenakan adanya Pasal 29 tersebut, MoU ini juga memiliki daya ikat yang kuat terhadap para pihak, hal ini dikarenakan tidak terlepas dari hakikat pembentukan MoU ini, yang merupakan Agrement is Agrement, yang berarti MoU yang dibuat oleh para pihak ini bersifat tertulis, mengikat bagi para pihak, mengatur hal yang pokok-pokok saja, terdapat jangka waktu berlakunya, dan dapat diberlakukan pasal-pasalnya seketika setelah disepakati. Oleh karena telah memenuhi unsur-unsur tersebut, MoU berlaku sebagai kontrak bagi para pihak, seperti yang di sebutkan dalam Pasal $1338^{38}$ ayat (1) KUHPer sebagai dasar yuridis, yang mengatakan “apapun yang dibuat sesuai kesepakatan kedua belah pihak, merupakan hukum yang berlaku baginya sehingga mengikat kedua belah pihak tersebut. Selain itu menurut asas kebebasan berkontrak dan asas konsensual maka hal apa saja asalkan halal menurut hukum dan telah secara bebas disepakati maka berlaku suatu perjanjian atau jika diterapkan secara tertulis maka hal tersebut bisa dikatakan sebagai kontrak. ${ }^{39}$

\section{Daya Ikat SKB}

Penerbitan SKB tentang Kode Etik Dan Pedoman Perilaku Hakim adalah atas perintah undang-undang, yaitu oleh ketentuan Pasal 41 ayat (3) Undang- Undang Nomor 48 Tahun 2009 tentang Kekuasaan Kehakiman dan Pasal 32 ayat (4) Undang-

\footnotetext{
${ }^{38}$ Terkait dengan asas kebebasan berkontrak, yang pada akhirnya menyatakan bahwa perjanjian yang telah disepakati oleh para pihak akan mengikat dan berlaku selayaknya undan-undang bagi para pihak tersebut. Lihat dalam Salim, H. S., Hukum Kontrak, Teori dan Teknik....,Op. Cit., hlm. 40.

${ }^{39}$ Munir Fuadi, Hukum Bisnis..., Op. Cit., hlm. 92-94.
} 
Undang Nomor 3 Tahun 2009 tentang Perubahan Kedua atas Undang-Undang Nomor 14 Tahun 1985 tentang Mahkamah Agung. Maka, atas dasar itulah SKB ini berlaku secara sah berdasarkan hukum dan harus dipatuhi serta dilaksanakan oleh seluruh hakim di jajaran kekuasaan kehakiman. SKB merupakan implementasi dan penjabaran lebih lanjut dari ketentuan undang-undang serta dimaksudkan untuk melaksanakan dan menegakkan kode etik dan pedoman perilaku hakim bagi hakim di dalam menjalankan tugas profesinya maupun dalam hubungan kemasyarakatan di luar kedinasan. Dengan demikian, SKB tentang Kode Etik dan Pedoman Perilaku Hakim mempunyai kekuatan hukum mengikat bagi pihak yang terlibat di dalam pembentukannya, dalam hal ini adalah KY dan MA.

Berdasarkan wawancara yang dilakukan oleh penulis dengan staf $\mathrm{KY}^{40}$ terkait dengan bagaimana sebenarnya daya ikat SKB ini terhadap pihak yang terkait dalam hal ini KY dan MA, menurut penuturannya:

“MA dan KY memposisikan SKB ini mengikat terhadap mereka, karena pembentukan SKB ini merupakan hasil dari diskusi dua lembaga tersebut, bahkan KY memposisikan SKB ini mengikat dikarenakan sebagai dasar KY dalam mengawasi, "mengadili" melalui Majelis Kehormatan Hakim (MKH), hanya saja saat ini secara operasional itu tidak mudah karena sifatnya makro dan hingga sekarang masih belum jelas mana ranah etik dan mana ranah teknis yudisial".

\section{Implikasi Dibentuknya MoU}

Implikasi dari dibentuknya MoU ini adalah berlakunya MoU layaknya sebagai undang-undang bagi KPK, Polri, dan Kejari. Hal ini dibuktikan dengan banyaknya pasal yang memuat hak dan kewajiban bagi para pihak yang terlibat dalam MoU ini. Di samping itu, dalam MoU selalu dicantumkan mengenai keterlibatan para pihak dalam setiap kegiatan, seperti yang tercantum dalam Pasal 5 huruf yang mengatakan bahwa "Pemantauan terhadap potensi penyimpangan pengelolaan keuangan dan kekayaan negara dalam pelaksanaan program pembangunan di pusat dan daerah dengan melibatkan petugas yang mewakili PARA PIHAK; dan huruf g, “Sosialisasi untuk meningkatkan kualitas pelayanan publik dan peran serta masyarakat dalam pencegahan tindak pidana korupsi, dengan melibatkan petugas yang mewakili PARA PIHAK." Adanya pengaturan ini membuktikan telah terjadi sinergi yang tepat dalam menjalankan keseluruhan kesepakatan yang dituangkan dalam MoU ini, maka untuk mensinergikan dan mewujudkan tujuan dibentuknya

${ }^{40}$ Wawancara dengan Elza Faiz, SH (Staf KY), pada tanggal 26 Februari 2013. 
MoU ini seluruh pihak terkait memiliki “keterikatan” terhadap lahirnya MoU ini, dengan kata lain MoU ini bersifat "mengikat" bagi para pihak.

Dalam Pasal 29 disebutkan bahwa "Apabila terdapat suatu ketentuan dalam Kesepakatan Bersama ini yang dilarang oleh ketentuan peraturan perundangundangan setelah ditandatanganinya Kesepakatan Bersama yang menyebabkan ketentuan tersebut menjadi tidak berlaku, maka hal tersebut tidak membatalkan ketentuan-ketentuan lainnya dalam Kesepakatan Bersama ini dan ketentuanketentuan lainnya dalam Kesepakatan Bersama ini tetap berlaku serta mengikat." Klausul ini semakin mempertegas bahwa MoU ini bersifat mengikat bagi para pihak, asalkan MoU ini tidak bertentangan dengan peraturan perundang-undangan yang lain. Serta ketentuan Pasal 30 ayat (1) yang mengatakan, “Kesepakatan Bersama ini berlaku selama 4 (empat) tahun dan mulai berlaku secara efektif terhitung sejak tanggal ditandatanganinya kesepakatan bersama", dengan adanya jangka waktu ini maka jelas daya ikat MoU ini adalah selama 4 (empat) tahun.

Dalam penutup di bagian akhir dikatakan: “Demikian Kesepakatan Bersama ini dibuat dengan semangat kerjasama yang baik untuk dipatuhi dan dilaksanakan oleh PARA PIHAK", yang menjadi fokus untuk menjawab apakah MoU ini mengikat para pihak adalah, kata-kata "dipatuhi dan dilaksanakan oleh para pihak" yang berarti MoU ini mengikat kepada para pihak dan sebagai bentuk keterikatan itulah maka, para pihak harus mentaati dan menjalankan MoU yang telah disepakati bersama.

\section{Implikasi Dibentuknya SKB}

Gagasan awal dibentuknya SKB ini adalah untuk mewujudkan suatu penegakan hukum dan mewujudkan keadilan sebagai proses pembangunan bangsa ke arah yang lebih baik. Untuk mewujudkan hal tersebutlah maka dibutuhkan adanya sinergisitas dari pihak-pihak terkait, dalam hal ini adalah Mahkamah Agung (KY) dan Komisi Yudisial (KY) yang dimaksudkan mengawal dan menegakkan martabat hakim, maka dari itu SKB yang dibentuk ini adalah mengenai kode etik dan pedoman perilaku hakim.

Dalam butir 3.1 SKB MA dan KY terdapat ketentuan yang mengatur kewajiban hakim, yakni: (1) Hakim wajib menghindari tindakan tercela; (2) Hakim, dalam hubungan pribadinya dengan anggota profesi hukum lain yang secara teratur beracara di pengadilan, wajib menghindari situasi yang dapat menimbulkan 
kecurigaan atau sikap keberpihakan; (3) Hakim dilarang mengadili perkara dimana anggota keluarga hakim yang bersangkutan bertindak mewakili suatu pihak yang berperkara atau sebagai pihak yang memiliki kepentingan dengan perkara tersebut; (4) Hakim dilarang mengizinkan tempat kediamannya digunakan oleh seorang anggota suatu profesi hukum untuk menerima klien atau menerima anggota-anggota lainnya dari profesi hukum tersebut; (5) Hakim dalam menjalankan tugas-tugas yudisialnya wajib terbebas dari pengaruh keluarga dan pihak ketiga lainnya; (6) Hakim dilarang menggunakan wibawa pengadilan untuk kepentingan pribadi, keluarga atau pihak ketiga lainnya; (7) Hakim dilarang mempergunakan keterangan yang diperolehnya dalam proses peradilan untuk tujuan lain yang tidak terkait dengan wewenang dan tugas yudisialnya. Adanya beberapa ketentuan yang mengatur terkait kewajiban hakim ini, tentunya memiliki implikasi, yakni bahwa hakim harus menempatkan SKB ini sebagai bagian dari aturan yang harus dipatuhi oleh pihak yang terkait selama tidak bertentangan dengan peraturan perundangundangan. Hal ini seperti yang disampaikan oleh Elza Faiz, salah satu staf KY, hal ini diperoleh dari hasil eksaminasi putusan $\mathrm{MA},{ }^{41}$ pada dasarnya SKB tersebut harus dipahami membuahkan implikasi mengikat bagi pihak yang terkait di dalamnya.

\section{Penutup}

Berdasarkan uraian di atas dapat disimpulkan sebagai berikut. Pertama, Surat Keputusan Bersama tentang Kode Etik dan Pedoman Perilaku Hakim ditinjau dari teori perundang-undangan dapat dikategorikan sebagai peraturan kebijakan, tetapi sebenarnya substansi yang ada dalam SKB tersebut adalah materi muatan peraturan perundang-undangan. Sedangkan MoU tentang Optimalisasi Pemberantasan Tindak Pidana Korupsi ditinjau dari teori perundang-undangan tidak dapat dikategorikan sebagai bagian dari peraturan perundang-undangan, karena MoU tidak tercantum dalam hierarki peraturan perundang-undangan serta MoU tidak memenuhi salah satu unsur suatu peraturan perundang-undangan yakni, berlaku dan mengikat secara umum, selain itu MoU merupakan bagian dari perjanjian/ kesepakatan yang tidak termasuk dalam kategori peraturan perundang-undangan. Kedua, SKB memiliki daya ikat dan berlaku sebagai aturan bagi MA dan KY. MoU

${ }^{41}$ Putusan MA Nomor : 36 P/HUM/2011, Keputusan Bersama Ketua Mahkamah Agung dan Ketua Komisi Yudisial. Nomor : 047/KMA/SKB/ IV/2009 Nomor : 02/SKB/P.KY/ IV/2009 tentang Kode Etik dan Pedoman Perilaku Hakim. 
berimplikasi mengikat bagi para pihak karena merupakan kategori MoU Agrement is Agrement yang mengikat layaknya sebagai undang-undang bagi para pihak berdasarkan ketentuan KUHPer Pasal 1338 ayat (1) dan menimbulkan implikasi MoU berlaku sebagai aturan bagi KPK, Polri, dan Kejari, sepanjang tidak bertentangan dengan peraturan perundang-undangan yang lain dan apabila isi MoU bertentangan dengan peraturan perundang-undangan lain, maka MoU dinyatakan tidak berlaku.

Berdasarkan kesimpulan di atas, peneliti memberikan beberapa saran sebagai berikut: pertama, seharusnya aturan seperti MoU dan SKB tidak perlu dibuat oleh lembaga dan/atau komisi negara, karena semua aturan yang terkait dengan lembaga dan/atau komisi negara seharusnya dibentuk dalam bentuk peraturan perundangundangan. Agar dalam pelaksanaannya tidak menimbulkan kerancuan atau tumpang tindih peraturan. Kedua, perlu adanya "penertiban" aturan yang dibuat oleh lembaga dan/atau komisi negara terkait materi dan bentuk aturannya, agar dalam penerapannya tidak terjadi tumpang tindih aturan lain. Ketiga, perlunya dibentuk suatu formulasi baku sebagai wadah peraturan-peraturan bersama yang dibentuk antarlembaga dan/atau komisi negara, yang tentunya harus dimasukkan dalam hierarki peraturan perundang-undangan sehingga tidak menimbulkan sesat tafsir.

\section{Daftar Pustaka}

Fuadi, Munir, Hukum Bisnis dalam Teori dan Praktek, Citra Aditya Bakti, Bandung. 2000.

Huda, Ni"matul \& R. Nazriyah, Teori E Pengujian Peraturan Perundang-Undangan, Cetakan Pertama, Nusa Media, Bandung , 2011.

HS, Salim, et, Al., Perancangan kontrak dan MoU, cetakan ketiga, sinar grafika, Jakarta, 2008.

, Hukum Kontrak (Teori dan Teknik Penyusunan Kontrak), cetakan ketujuh, Sinar Grafika, Jakarta, 2010.

Marbun, SF. dan Moh. Mahfud MD, Pokok-Pokok Hukum Administrasi Negara, Cetakan Kelima, Liberty, Yogyakarta, 2009.

Rajagukguk, Erman, Kontrak Dagang Internasional dalam Praktek di Indoesia, FH UI dan Elips Project, Jakarta, 1994.

Situni, F.A. Whisnu, Identifikasi dan Reformasi Sumber-Sumber Hukum Internasioanal, Cetakan I, Mandar Maju, Bandung, 1989. 
Soekanto, Soerjono dan Purnadi Purbacaraka, Perihal kaidah Hukum, PT Citra Aditya, Bandung, 1989.

Yuliandri, Asas-Asas Pembentukan Peraturan Perundang-undangan yang Baik, Cetakan Pertama, PT. Raja Grafindo Persada, Jakarta, 2009.

http:// www.tribunnews.com/2012/10/08/sby-kasus-simulator-sim-serahkan-kekpk.html yang direkam pada Senin, 8 Oktober 2012 21:03 GMT.

http//mediabersama.com/index.php/option Dyah Aryani P, Sekilas tentang MoU.html yang direkam pada 6 september 2009). 